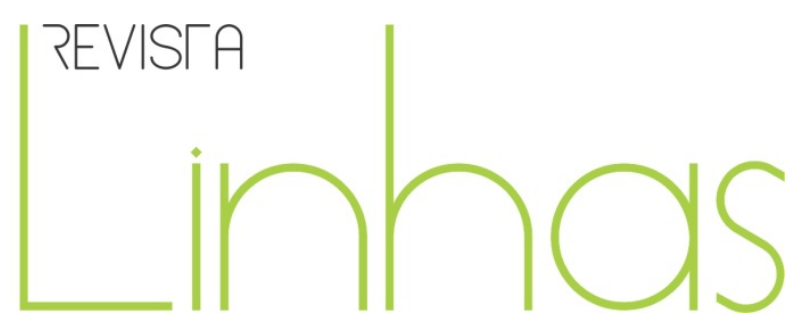

\title{
O cuidado social e jurídico com menores "abandonados": uma questão de ordem
}

AREND, Sílvia Maria Fávero. Histórias de Abandono: Infância e Justiça no Brasil (década de 1930). Florianópolis: Editora Mulheres, 2011.

\author{
Douglas Josiel Voks \\ Mestrando no Programa de Pós- \\ Graduação em História na Universidade \\ do Estado de Santa Catarina - \\ PPGE/UDESC. \\ douglas_voks@hotmail.com
}

\section{Para citar esta resenha:}

VOKS, Douglas Josial. O cuidado social e jurídico com menores "abandonados": uma questão de ordem. Revista Linhas, Florianópolis, v. 14, n. 26 , jan./jun. 2013. p. $312-315$.

DOI: $10.5965 / 1984723814262013312$

http://dx.doi.org/10.5965/1984723814262013312 
Com a emergência do campo de estudos da história da infância no Brasil, crianças e jovens passaram a ser cada vez mais percebidos como sujeitos históricos. Neste sentido, diversas publicações vêm buscando contribuir para esclarecer e preencher lacunas que levem em consideração esta fase da vida. Além disto, busca-se atravessar os muros acadêmicos e reconstruir, para o grande público, trajetórias e histórias de "pequenos" indivíduos que, embora por vezes esquecidos, são fundamentais para compreender a nossa História.

Foi tendo por fundo este cenário que a historiadora Sílvia Maria Fávero Arend publicou a obra Histórias de Abandono - Infância e Justiça no Brasil (década de 1930), em 2011, pela Editora Mulheres, inicialmente produzida em forma de tese. Ao longo de todo o trabalho, o leitor se depara com uma narrativa que, sem fugir das exigências do campo historiográfico, se aproxima, de acordo com Joana Maria Pedro no prefácio, de uma literatura. Nesse livro, através de autos de busca e apreensão, autos de processo-crime, autos de abandono, entre tantas outras fontes documentais, a autora reconstrói trajetórias de sujeitos anônimos e mostra como a infância e a juventude foram transformadas em problema social na década de 1930.

Histórias de Abandono: Infância e Justiça no Brasil (década de 1930) divide-se em cinco capítulos, todos norteados pelas discussões teóricas propostas por Michel Foucault acerca do problema da gestão da população em nível individual e coletivo no Estado Moderno no mundo ocidental. Neste processo histórico, família e Estado adquirem papel fundamental.

No primeiro capítulo, intitulado "Na cidade os primeiros parentes são os vizinhos", a autora discute as relações existentes entre as redes sociais assistenciais, buscando compreender por que uma parcela da população pobre de Florianópolis, em 1930, foi incluída no programa social instituído pelo Poder Judiciário. A maior parte das crianças e jovens registrados eram filhos e filhas de famílias que haviam migrado recentemente para a localidade. Neste capítulo, a autora apresenta um panorama da capital, indicando que na década de 1930 a cidade passava por forte crise econômica.

No segundo capítulo, cujo título é "Os filhos da mãe", discute os arranjos familiares de crianças e jovens considerados abandonados pelo Juizado de Menores na 
década referida. A autora analisa, valendo-se de um vasto número de fontes documentais, o cotidiano de pais e mães consanguíneos e as motivações que os levavam a transferir seus filhos para outros lares. Aponta as relações que envolvem o mundo do trabalho e descreve as condições de pobreza dos pais, além de comentar discursos que almejavam "transformar" o homem pobre brasileiro em trabalhador e provedor do lar.

No terceiro capítulo, denominado "Um poder sobre a vida", destaca as ações de cunho assistencial, desenvolvidas em prol da infância e da juventude pobre em Desterro, depois Florianópolis, ${ }^{1}$ buscando perceber as diferenças entre essas práticas e as que eram realizadas pelo Juizado de Menores. Neste capítulo, a autora analisa primeiramente como e por que se instituiu o Juizado Privativo de Menores na capital do estado de Santa Catarina. Posteriormente, descreve quais foram os programas sociais implementados pelas autoridades judiciárias com o propósito de resolver os "problemas" relacionados à infância e à juventude. Entre estas ações, destaca a transferência de crianças e jovens para famílias substitutas e a liberdade vigiada de "menores" considerados infratores.

No quarto capítulo, "Os filhos do Estado", a historiadora mostra como a noção de “menor abandonado”, constante no Código de Menores de 1927, foi operacionalizada pelas autoridades judiciárias da capital do estado de Santa Catarina para transferir as crianças pobres/órfãos e os considerados infratores (através do instituto jurídico da guarda) para lares de guardiões e guardiãs. Nesse processo, registra uma mudança no âmbito do discurso relativo à infância no Brasil: deixava-se de associar a infância pobre a questões morais, e se começava a percebê-la como um grave problema social.

No quinto e último, "Os filhos de criação", a autora buscou conhecer as experiências de filhas e filhos dos pobres urbanos nos lares guardiões na década de 1930 e 1940. Inicialmente, traça um perfil socioeconômico desses tutores, no intuito de compreender por que acolhiam tais crianças em suas casas. Em seguida, descreve os labores desempenhados por essas crianças e jovens nos lares de seus responsáveis. A autora constatou que as famílias substitutas com menor poder aquisitivo as abrigavam pelo pagamento auferido do Estado (soldada) e em função do trabalho infanto-juvenil,

${ }^{1} \mathrm{Em}$ 1894, ao fim da Revolução Federalista, Desterro teve o nome alterado para Florianópolis, em homenagem ao então presidente da República, Floriano Peixoto. 
pois as crianças poderiam fazer pequenos trabalhos que se converteriam em mais renda para a família. As famílias mais abastadas acolhiam os considerados "abandonados", visando sobretudo a obter mão-de-obra gratuita para seus lares.

Por fim, a autora reflete sobre a visão então predominante de história do Brasil, concentrada no que se passava na Região Sudeste, classificando o que se passava fora dessa área como história regional.

O livro ultrapassa os limites de seu título, podendo ser utilizado para compreender o panorama brasileiro da época, já que os processos relativos à operacionalização da legislação (Código de Menores de 1927) e à institucionalização de Juizados de Menores (que se deu em diversas capitais dos estados da Federação no período) podem ser generalizados para outras regiões do País.

Conclui-se, da leitura desse trabalho, que contribui significativamente para a História, uma vez que ajuda a compreender questões do presente. Através desta obra, pode-se ter acesso a um vasto conhecimento sobre a institucionalização de práticas que não necessariamente tinham como prioridade a introdução de direitos de crianças e jovens, mas que representam um passo importante rumo à legislação atualmente em vigor no Brasil, com destaque para o Estatuto da Criança e do Adolescente.

Universidade do Estado de Santa Catarina - UDESC Programa de Pós-Graduação em Educação - PPGE Revista Linhas Volume 14 - Número 26 - Ano 2013 revistalinhas@gmail.com 